\title{
ПСИХОЛОГІЧНІ ХАРАКТЕРИСТИКИ ОСОБИСТОСТІ ПСИХОЛОГА В ПАРАДИГМАХ ІСНУЮЧИХ КЛАСИФІКАЦІЙ ПРОФЕСІЙ
}

УдК: 159.923

\section{Власенко Андрій Анатолійович}

Аспірант кафедри психологї управління, Державний вищий навчальний заклад «Університет менеджменту освіти» Національної академії педагогічних наук, Київ (Украӥни)

\begin{abstract}
Анотація. $\quad$ у статті автор, на основі теоретичного аналізу сучасної наукової літератури, виокремлює найбільш застосовні варіанти психологічних класифікаџій професій. Визначено місие професії психолога та психологічний тип професї психолога в системах даних класифікацій. Розглядається трактування класифікаџї професійних орієнтацій особистості у вітчизняній та зарубіжній психології. Виявлено основні психологічні характеристики професії психолога в умовах трансформацї сучасного суспільства та реформування украӥнської школи, вимоги до особистості психолога, особливості ставлення психолога до своєї діяльності. Підкреслюється важливість психологічного супроводу особистості на всіх етапах ї̈ розвитку.
\end{abstract}

Ключові слова: реформування украӥнської школи, психологічна класифікація професій, професія психолога, психологічно значущі характеристики психолога.

Постановка проблеми. В умовах трансформації як сучасного суспільства, так й реформування української школи, визначення психологічно важливих якостей психолога $є$ дуже важливим.

Саме тому прийнятий 5 вересня 2017 року Верховною Радою і затверджений Президентом 25 вересня 2017 року Закон України «Про освіту» стверджує курс на реформування української школи. Визначаючи зв'язок сталого розвитку України з іiі європейським вибором, цей документ є новим щаблем інтег- рації України в світову спільноту [1].

У цілях, визначених Організацією Об'єднаних Націй в документі «Перетворення нашого світу: Порядок денний в галузі сталого розвитку на період до 2030 року», вказується на те, що сталий розвиток безпосередньо пов'язано з побудовою відкритого суспільства [11]. Дж. Сорос, переносячи принцип фальсифікації наукових знань К. Поппера на суспільні процеси, визначає один з базових постулатів відкритого суспільства, як безперервне вдосконалення, реформування всіх соціальних 
інститутів [19]. Дане положення, посилюючи наголос на перманентно мінливої структурі середовища проживання, визначає посилення наголосу і на необхідності психологічної корекції особистості індивіда. Актуалізація цього соціального запиту збільшує значення прикладної психології серед практичних наук.

Закон «Про освіту» метою системи освіти України визначає всебічний розвиток людини як особистості [1]. У даній парадигмі реформи системи освіти важливість ролі пси-

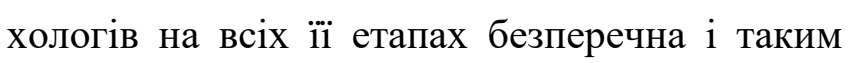
чином перегукується зі світовою тенденцією зростання ролі прикладної психології.

3 іншого боку, науково-технічна революція, багато в чому визначає конфігурацію громадських взаємин, якісно перетворюючи структуру і динаміку продуктивних сил, змінюючи психологічні вимоги, як до окремого індивіда, так і цілим соціальним групам, визначаючи психології особливе, важливе місце в структурі наук, які є детермінантою прогресу загальнолюдського, істотно підсилює значення професії психолога в соціумі. Іншими словами, революційні перетворення в сфері людської діяльності тягнуть за собою корінні зміни в сфері розуміння психологічних процесів, що лежать в основі цієї діяльності, формують соціальний попит на їх психологічний супровід [6] .

Саме тому, зростаюча роль професії психолога в умовах реформування української школи знаходиться в мейнстрімі загального посилення ролі психології, як науки, в перманентно мінливому соціумі.

Психологічна класифікація професій, забезпечуючи теоретичну базу досліджень професії психолога, як окремої професійної групи, є наріжним каменем досліджень даної групи, особистості індивідуумів в контексті їх трудової діяльності.

Таким чином застосування методологій, пов'язаних $з$ психологічною класифікацією професій, до аналізу професії психолога актуальна вимога сучасності, важлива, невід’ємна частина психологічного супроводу реформи української освіти.

Метою статті $\epsilon$ визначення основних психологічно значущих характеристик психолога на основі найбільш прийнятних класифікацій професій.

Завданнями статті є: 1. Проаналізувати найбільш поширені, з існуючих в сучасній науковій літературі, класифікації професій. 2. Визначити психологічний тип професії психолога в системах цих класифікацій. 3. Виявити основні психологічні характеристики професії психолога в умовах сьогодення.

\section{Аналіз останніх досліджень і публіка-} цій. На даний момент, тема класифікації професій досліджена в достатній мірі в роботах вітчизняних вчених $[4 ; 9 ; 13$ тощо], а також вченими зарубіжними $[17 ; 18 ; 15]$.

3 усіх існуючих зараз варіантів психологічних класифікацій професій найбільшого поширення набули класифікація 
Дж. Л. Голланда [16], заснована на його теорії професійного вибору і чотириярусна класифікація Є. О. Клімова [10].

Крім вищевказаних підходів застосовуються і інші методики, більш локальної дії які, відповідно, не отримали такого широкого використання. Наприклад, методика оцінки діяльності О. Ліпмана (опитувальний лист, адаптований М. А. Дмитрієвою), як продукт його психофізичного підходу [8], історична класифікація професій, що зародилася в рамках проекту HISMA координатором якого виступає Марко Х. Д. ван Леувен [17 та ін.].

Виклад основного матеріалу дослідження. Усі відомі на даний момент психологічні класифікації професій, використовуючи оригінальні підходи, як правило, ніяк не узгоджені між собою, з чого випливає, що дослідження в цій галузі знаходяться в екстенсивній стадії розвитку.

Виявлено, що в світовій практиці застосовується, переважно, класифікація Дж. Л. Голланда, який вперше запропонував враховувати індивідуальні властивості особистості в процесі вибору професії. Досліджуючи властивості особистості індивідів, зайнятих в різних професіях, він виділив такі типи професійних особистостей: руховий, інтелектуальний, естетичний, підтримуючий, переконливий і відповідний. В ході подальших досліджень ці типи були їм змінені на: реалістичний (діяльний), дослідницький (мислителі), художній (творчий), соціальний (помічники), підприємливий (ті що переконують) та звичайний (організатори) [18].

У сучасній вітчизняній психології застосовується дещо змінене трактування класифікації професійних орієнтацій особистості Дж. Л. Голланда: реалістичний тип (створення матеріальних речей, обслуговування технологічних процесів і технічних пристроїв), інтелектуальний (розумова праця), художній (творчість), соціальний (взаємодія із соціальним середовищем), підприємницький (керівництво людьми і бізнес), конвенціональний (чітко структурована діяльність). Як бачимо, тип дослідницький трактується, як тип інтелектуальний, тип підприємливий, як тип підприємницький, а тип звичайний, як конвенціональний. Типи особистості, перебуваючи в вершинах шестикутника 3 вписаною гексаграмою, визначають сумісність особистості і середовища [4].

Необхідно відзначити, що тестування Дж. Л. Голланда «самоспрямований пошук» (Self-Directed Search), що базується на даній класифікації, отримавши широке застосування в сфері консультування з питань кар'єри та профорієнтації, в процесі адаптації в багатьох країнах піддається істотним модифікаціям. Це пояснюється концептуальними, культурними та мовними відмінностями окремих регіонів [15]. Методика була адаптована
А. Н. Воробйовим,
І. Г. Сеніним
В. І. Чірковим в 1993 році, і отримала назву «Опитувальник професійних вподобань» [5]. 
У цій системі класифікації, професія «психолог» відноситься до типу «соціальний», котрий володіє найбільшим ступенем сумісності 3 типом підприємницький і художній, a найменшою - з реалістичним. Однак, оскільки соціальний тип характеризує високі адаптаційні показники, володіння соціальними вміннями, що дозволяють встановлювати тісний контакт з соціальним середовищем, високу активність, то і оцінка більшою або меншою сумісності цієї професії в порівнянні з іншими типами професій набуває деяку умовність.

3 початку 1970-х рр. в Радянському союзі затверджується своя психологічна класифікація професій, розроблена Є. О. Клімовим. Нині, традиційно, ця класифікація є найбільш поширеною в країнах, розташованих на території пострадянського простору.

Класифікація Є. О. Клімова, яка побудована за багатофакторним принципом, маючи в першому ярусі п'ять типів професій, у другому - три, в третьому - чотири, і в четвертому - чотири, є більш точною, але і більш складною структурно. Наслідком цього $є$ те, що методика самого Є. О. Клімова, діагностуючи схильності до різного роду професій використовує лише п'ять типів професій першого ярусу («людина-жива природа», «людинатехніка», «людина-людина», «людина-знакова система», «людина-художній образ») [10].

Професія «психолог», згідно даної класифікації, потрапляє в групу «людиналюдина» першого ярусу, ті що перетворюють
- другого, переважання функціональних засобів праці - третього і робота в умовах звичайного побутового мікроклімату - четвертого. Пропозиція Є. О. Клімова $з$ літерного позначення типу професії можливо є спробою мікшувати розтягнутість цього визначення.

Таким чином, дана класифікація, в порівнянні 3 класифікацією Дж. Л. Голланда, $є$ більш глобальною за змістом і академічною за формою, що дещо ускладнює, на наш погляд, iï використання практикуючими психологами. Ми б виділили цей факт, як важливу причину, 3 якої класифікація Є. О. Клімова, будучи більш універсальною, не отримала широкого застосування за межами пострадянського простору.

Виявлено, що основні психологічно значущі характеристики психолога, як типу «соціального», згідно класифікації Дж. Л. Голланда, є:

- орієнтація на спілкування і взаємодію з людьми;

- яскраво виражені комунікативні здібності;

- співчуття і розуміння інших людей;

- прагнення вирішувати проблеми, враховуючи емоції і почуття;

- здатність до співпереживання та співчуття.

Згідно класифікації Є. О. Клімова, основні психологічно значущі характеристики психолога, як типу «людиналюдина» (соціономічний тип професій, якій 
передбачає постійну роботу з людьми і постійне спілкування в ході професійної діяльності), є [7]: розвинені комунікативні здібності; емоційна стійкість; можливість швидкого переключення уваги; емпатія; спостережливість; організаторські здібності.

Дослідження психологічно значущих характеристик психолога, що проводилися в подальшому, в значній мірі спиралися на ці базові характеристики.

Так В. Г. Асєєв, для успішного виконання професійних функцій психолога виокремлює [3]: переконання; педагогічні здібності; інтереси; професійна пам'ять; мислення; увага; педагогічна спрямованість думки; працездатність; емоційність; моральний потенціал особистості.

I. П. Андрійчук, акцентуючи увагу на ставленні психолога до своєї професійної діяльності, виокремлює [2]: позитивне ставлення до суб'єкта та об'єкта професійного процесу; гуманістичною спрямованістю професійної діяльності; емоційною насиченістю позитивного ставлення до діяльності, його особистісним зацікавленням; позитивним ставленням до самого себе; впевненістю у собі, емоційною рівновагою, стресостійкістю, креативністю, прагненням до досягнень, відповідальністю, комунікабельністю.

I. I. Солійчук в своїх дослідженнях наголошує увагу на вольових характеристиках особистості психолога [14]: цілеспрямованість (керування в роботі певною метою); самовла- дання і витримка (збереження самоконтролю в будь-якій ситуації); наполегливість (тривале збереження зусиль при досягненні поставленої мети); рішучість (своєчасно приймати продумані рішення і без зволікань приступати до їх виконання); самостійність (відносна незалежність від зовнішніх впливів); самокритичність (вміння помічати свої помилки, неправильні дії та прагнення їх виправити).

Спираючись на дослідження в даній області, О. Ю. Пряжнікова виявляє такі вимоги до особистості психолога [12]:

- психолог повинен мати високі (загальні) розумові здібності, бути проникливим, розважливим, вільнодумцем, вдумливим аналітиком, експериментатором;

- психолог соціабельний, любить працювати з людьми, радіє соціальному визнанню (схвалення), великодушний до людей, легко формує активні групи, добре запам'ятовує імена людей, люб'язний, тактовний, дипломатичний в спілкуванні;

- він любить спільні дії, підпорядковує інтереси особистості груповим інтересам, совісний, сумлінний, має почуття обов'язку i відповідальності, сильний, енергійний, вміє підпорядкувати собі. Він сміливий, швидко вирішує практичні питання;

- психолог емоційно стійкий, витриманий, спокійний, реально зважує

- обстановку, стійкий до стресу.

Висновки та перспективи подальших досліджень. 3'ясовано, що на сьогодні, 
для визначення психологічного типу професії психолога, найбільш застосовними є психологічна класифікація професій Дж. Л. Голланда (тип «соціальний») і класифікація Є. О. Клімова (тип «людина-людина»). Існування різних підходів до даного питання визначають перспективу досліджень 3 їх уніфікації.

Виокремлено основні психологічно значущі характеристики психолога, згідно 3 класифікацією Дж. Л. Голланда і класифікацією Є. О. Клімова, які багато в чому перетинаючись, визначаються, як: орієнтація на спілкування і взаємодія з людьми, комунікативні здібності, емпатія тощо.

Також 3'ясовано, що сучасні наукові дослідження роблять акцент на поглибленні досліджень психологічно значущих характеристик психолога: вольові характеристики особистості психолога, позитивний психологічний настрой в процесі своєї професійної діяльності, тощо.

Надалі планується провести дослідження зв'язків психологічно значущих характеристик особистості психолога і когнітивних характеристик його свідомості.

\section{Перелік використаних джерел:}

1. Закон України про освіту / Відомості Верховної Ради (ВВР), № 38-39, Київ : 2017. — 380 с.

2. Андрійчук І. П. Формування позитивної Я-концепції особистості майбутніх практичних психологів в процесі професійної підготовки : автореф. дис. на здобуття на- ук. ступеня канд. психол. наук : спец. 19.00.07 «Педагогічна та вікова психологія» / І. П. Андрійчук. Тернопіль, 2003. - 20 с.

3. Асеев В. Г. Психология труда / В. Г. Асеев. - Иркутск : изд-во Иркутского университета, 2005. - 342 с.

4. Баклицький I. О. Психологія праці: підруч. [для студ. вищ. навч. закл.] / І. О. Баклицький. - Київ : Знання, 2008. - 655 c.

5. Воробьёв А. И. Опросник профессиональных предпочтений по Холланду / А. Н. Воробьёв, И. Г. Сенин, В. И. Чирков. - Москва. : Когито-Центр, 2013. - 20 с.

6. Ильин Е. П. Работа и личность. Трудоголизм, перфекционизм, лень / Е. П. Ильин. - Санкт-Петербург : Питер, 2011. - $224 \mathrm{c}$.

7. Кореко A. В. Типы профессий по классификации Е. А. Климова [Електронний ресурс] / А. В. Кореко // Сайт образовательного проекта «Letopisi.ru», 2007. Режим доступа: http://letopisi.org/index.php/ Типы профессий по классификации Е.А.Климова

8. Маклаков А. Г. Профессиональный психологический отбор персонала. Теория и практика : Учеб. для вузов / А. Г. Маклаков. - Санкт-Петербург : Питер, 2016. $480 \mathrm{c}$.

9. Москальова А. С. Особистісний потенціал подолання професійних криз керівниками освітніх організацій як чинник їх конкурентоздатності / А. С. Москальова // Конкурентологія та ринок праці: психологічні аспекти : Тези I Міжнародної науково-практичної конференції (м. Київ, 8-9 грудня 2016 р.) [Електронний ресурс] / ДВНЗ «Університет менеджменту освіти». - Київ, 2016. - 54-56 с. - Режим доступу: http://umo.edu.ua/ konferenciji/i-mizhnarodna-naukovo-praktichnakonferencija-z-temi-konkurentologhija-ta-rinok-pracipsikhologhichni-aspekti

10. Носкова О. Г. Психология труда : Учеб. пособие [для студ. высших учеб. заведений] / О. Г. Носкова // под ред. Е. А. Климов. - Москва : Академия, 2004. $384 \mathrm{c}$.

11. Организациии Объединенных Наций «Преобразование нашого мира: Повестка дня в области 
устойчивого развития на период до 2030 года». [Електронний ресурс] - Режим доступа : http:// www.un.org/sustainabledevelopment/sustainabledevelopment-goals.

12. Пряжникова Е. Ю. Профориентация: Учеб. пособие для студ. висш. учеб. заведений / Е. Ю. Пряжникова , Н. С. Пряжников. - Москва : Издательский центр «Академия», 2005. - 496 с.

13. Розвиток професійної орієнтації в Україні : наук.допом. бібліогр. покажч. [Електронний ресурс] / АПН України, ДНПБ України ім. В. О. Сухомлинського [та ін.] ; [упоряд.: Л. О. Пономаренко, Н. А. Стельмах, Л. І. Ніколюк ; наук. ред.: Рогова П. І., Чепурна Н. М.; наук. консультант Мельник О. В. ; бібліогр. ред. Пономаренко Л. О.]. - Київ. ; Черкаси: [б. в.], 2009. - 196 с. Режим доступу: https://studfiles.net/preview/5263516/

14. Солійчук I. I. Теоретико-методологічний аналіз проблеми готовності практичного психолога до професійної діяльності / I. І. Солійчук // Проблеми сучасної психології. Зб. наук. праць Кам'янець-Подільського національного університету ім. І. Огієнка, Ін-ту психології ім. Г. С. Костюка АПН України. - Випуск 19. - Кам'янець-Подільський: «Аксіома», 2013. - 657-667 с.

15. International Handbook of Career Guidance / [James A., van Esbroeck et al.] ; Editors: Athanasou, James A., van Esbroeck, R. (Eds.). - Springer : Springer Netherlands, 2008. - 744 p.

16. Holland John L. Psychological Classification of Occupations / John L. Holland and Others [Electronic resource] / Johns Hopkins University, Md. Center for the Study of Social Organization of Schools. - Baltimore, 1970. - 68 p. - Access mode : http://files.eric.ed.gov/ fulltext/ED044534.pdf

17. Marco H. D. Van Leeuwen HISCO. Historical International Standard of Occupations /

Marco H. D. Van Leeuwen, Ineke Maas, Andrew Miles. Leuven.: Leuven University Press, 2002. — 441 p.

18. Nauta Margaret M. The Development, Evolution, and Status of Holland's Theory of Vocational Personalities: Reflections and Future Directions for Counseling
Psychology : Journal of Counseling Psychology [Electronic resource] / American Psychological Association. - 2010, Vol. 57, No. 1, 11-22 - Access mode : https:// www.counseling.org/docs/david-kaplan's-files/nauta.pdf 19. Soros G. The bubble of American supremacy : correcting the misuse of American power / G. Soros New York : Public Affairs, 2004. — 207 p.

\section{References (Transliteration):}

1. Zakon Ukrayiny pro osvitu / Vidomosti Verkhovnoyi Rady (VVR), № 38-39, Kyyiv : 2017. — 380 s.

2. Andrijchuk I. P. Formuvannya pozytyvnoyi Yakoncepciyi osobystosti majbutnikh praktychnykh psykhologiv $\mathrm{v}$ procesi profesijnoyi pidgotovky : avtoref. dys. na zdobuttya nauk. stupenya kand. psykhol. nauk : specz. 19.00.07 «Pedagogichna ta vikova psykhologiya»/ I. P. Andrijchuk. - Ternopil', 2003. - 20 s.

3. Aseev V. G. Psihologija truda / V. G. Aseev. - Irkutsk : izd-vo Irkutskogo universiteta, 2005. - $342 \mathrm{~s}$.

4. Baklyczkyj I. O. Psykhologiya praci: pidruch. [dlya stud. vyshh. navch. zakl.] / I. O. Baklyczkyj. - Kyyiv : Znannya, 2008. - $655 \mathrm{~s}$.

5. Vorob'jov A. I. Oprosnik professional'nyh predpochtenij po Hollandu / A. N. Vorob'jov, I. G. Senin, V. I. Chirkov. Moskva. : Kogito-Centr, 2013. - 20 s.

6. Il'in E. P. Rabota i lichnost'. Trudogolizm, perfekcionizm, len' / E. P. Il'in. - Sankt-Peterburg : Piter, 2011. - $224 \mathrm{~s}$.

7. Koreko A. V. Tipy professij po klassifikacii E. A. Klimova [Elektronnij resurs] / A. V. Koreko // Sajt obrazovatel'nogo proekta «Letopisi.ru», 2007. - Rezhim dostupa: http://letopisi.org/index.php/ Tipy professij po klassifikacii E.A.Klimova

8. Maklakov A. G. Professional'nyj psihologicheskij otbor personala. Teorija i praktika : Ucheb. dlja vuzov / A. G. Maklakov. — Sankt-Peterburg : Piter, 2016. - $480 \mathrm{~s}$.

9. Moskal ova A. S. Osobystisnyj potencial podolannya profesijnykh kryz kerivnykamy osvitnikh organizacij yak 
chynnyk yikh konkurentozdatnosti / A. S. Moskal ova // Konkurentologiya ta rynok praci: psykhologichni aspekty : Tezy I Mizhnarodnoyi naukovo-praktychnoyi konferenciyi (m. Kyyiv, 8-9 grudnya 2016 r.) [Elektronnyj resurs] / DVNZ «Universytet menedzhmentu osvity». - Kyyiv, 2016. - 54-56 s. - Rezhym dostupu: http://umo.edu.ua/ konferenciji/i-mizhnarodna-naukovo-praktichna-

konferencija-z-temi-konkurentologhija-ta-rinok-praci-

psikhologhichni-aspekti

10. Noskova O. G. Psihologija truda: Ucheb. posobie [dlja stud. vysshih ucheb. zavedenij] / O. G. Noskova // pod red. E. A. Klimov. — Moskva : Akademija, 2004. — 384 s.

11. Organizacii Objedinennyh Nacij «Preobrazovanie nashogo mira: Povestka dnja v oblasti ustojchivogo razvitija na period do 2030 goda». [Elektronnij resurs] Rezhim dostupa : http://www.un.org/ sustainabledevelopment/sustainable-development-goals.

12. Prjazhnikova E. Ju. Proforientacija: Ucheb. posobie dlja stud. vissh. ucheb. zavedenij / E. Ju. Prjazhnikova, N. S. Prjazhnikov. - Moskva : Izdatel'skij centr «Akademija», 2005. $-496 \mathrm{~s}$.

13. Rozvytok profesijnoyi oriyentaciyi v Ukrayini : nauk.dopom. bibliogr. pokazhch. [Elektronnyj resurs] / APN Ukrayiny, DNPB Ukrayiny im. V. O. Sukhomlyns ’kogo [ta in.] ; [uporyad.: L. O. Ponomarenko, N. A. Stel'makh, L. I. Nikolyuk ; nauk. red.: Rogova P. I., Chepurna N. M.; nauk. konsul'tant Mel’nyk O. V. ; bibliogr. red. Ponomarenko L. O.]. - Kyyiv. ; Cherkasy: [b. v.], 2009. - 196 s. - Rezhym dostupu: https://studfiles.net/preview/5263516/

14. Solijchuk I. I. Teoretyko-metodologichnyj analiz problemy gotovnosti praktychnogo psykhologa do profesijnoyi diyal'nosti / I. I. Solijchuk // Problemy suchasnoyi psykhologiyi. Zb. nauk. pracz' Kam'yanecz' Podil's`kogo nacional ’nogo universytetu im. I. Ogiyenka, In-tu psykhologiyi im. G. S. Kostyuka APN Ukrayiny. Vypusk 19. - Kam'yanecz`-Podil`s`kyj: «Aksioma», 2013. $-657-667 \mathrm{~s}$.

15. International Handbook of Career Guidance / [James A., van Esbroeck et al.] ; Editors: Athanasou, James A., van Esbroeck, R. (Eds.). - Springer : Springer
Netherlands, 2008. - 744 p.

16. Holland John L. Psychological Classification of Occupations / John L. Holland and Others [Electronic resource] / Johns Hopkins University, Md. Center for the Study of Social Organization of Schools. - Baltimore, 1970. - 68 p. - Access mode : http://files.eric.ed.gov/ fulltext/ED044534.pdf.

17. Marco H. D. Van Leeuwen HISCO. Historical International Standard of Occupations

Marco H. D. Van Leeuwen, Ineke Maas, Andrew Miles. Leuven.: Leuven University Press, 2002. - 441 p.

18. Nauta Margaret M. The Development, Evolution, and Status of Holland's Theory of Vocational Personalities: Reflections and Future Directions for Counseling Psychology : Journal of Counseling Psychology [Electronic resource] / American Psychological Association. - 2010, Vol. 57, No. 1, 11-22 - Access mode : https:// www.counseling.org/docs/david-kaplan's-files/nauta.pdf 19. Soros G. The bubble of American supremacy : correcting the misuse of American power / G. Soros New York : Public Affairs, 2004. — 207 p.

\section{Vlasenko Andrii}

PhD student of Department of management psychology, University of Education Management of the National Academy of Educational Sciences of Ukraine, Kiev (Ukraine)

\section{PSYCHOLOGICAL FEATURES OF THE PSYCHOLOGIST'S PERSONALITY IN THE PARADIGMS OF THE EXISTING CLASSIFICATIONS OF OCCUPATIONS}

\section{ABSTRACT}

The article presents a detailed analysis of social trends, which determine the significance of studying psychologist's personal features. Analysis of the relevant Ukrainian and foreign scientific literature allowed the author to identify the 
most applicable psychological classifications of occupations.

The author discusses the place of the profession of a psychologist in J. L. Holland classification of occupations as the most popular Western occupational classification and in E. Klimov four-level classification of occupations as the most popular psychological occupational classification among Ukrainian psychologists and managers. The author analyzes some aspects of these classifications from the theoretical and practical perspectives.

Based on the place of the profession of a psychologist in these classifications, the article explores the main psychological characteristics of the profession of a psychologist paying special attention to some important aspects and differences in the definitions of this profession in various occupational classifications as well as different hierarchies of the main psychological characteristics of the profession of a psychologist.

J. Holland and E. Klimov classifications distinguish quite similar psychological attributes of the individual to make a good psychologist, which include, among others, good communicative skills, empathy and tolerance.

The author also analyzes the leading research trends in studying the profession of a psychologist and makes conclusions about the increased role of psychologists in today's difficult social and economic situation in Ukraine, researcher's close attention to this profession as well as individual's profession-relevant psychological features.

The author describes the place of the profession of a psychologist in different foreign and Ukrainian occupational classifications and discusses the main psychologist's professioncritical attributes. The author also makes conclusions about the increased role of psychologists in today's difficult social and economic situation in Ukraine.

Key words: Ukrainian school reform, psychological classification of occupations, profession of a psychologist, psychologist's professioncritical attributes.

\section{Власенко Андрей Анатолиевич}

Аспирант кафедры психологии управления Государственного высшего учебного заведения "Университет менеджмента образования» Национальной академии педагогических наук Украины, г. Киев (Украина)

\section{ПСИХОЛОГИЧЕСКИЕ ХАРАКТЕРИСТИКИ ЛИЧНОСТИ ПСИХОЛОГА В ПАРАДИГМАХ СУЩЕСТВУЮЩИХ КЛАССИФИКАЦИЙ ПРОФЕССИЙ}

Аннотация. В статье автор, на основе теоретического анализа современной научной литературы, выделяет наиболее применимые варианты психологических классификаций профессий. Определяется место профессии психолога и психологический тип профессии «психолог» в системе данных классификаций. Расматривается трактовка классификации профессиональных ориентаций личности в отечественной и зарубежной психологии. Вы- 
явлены основные психологические характеристики профессии психолога в условиях трансформации современного общества и реформирования украинской школы, требования к личности психолога, особенности отношения психолога к своей деятельности. Подчеркивается важность роли психолога в развитии личности на всех этапах ее развития.

Ключевые слова: реформирование украинской школы, психологическая классификация профессий, профессия психолога, психологически значимые характеристики психолога. 